\title{
The Influence of Adhesive on Roof Tiles Product from Water Hyacinth Fiber Residues
}

\author{
Arkom Pasilo*, Umphisak Teeboonma \\ Department of Mechanical Engineering, Faculty of Engineering, Ubon Ratchathani University, Ubon Ratchathani, 34190, Thailand
}

\begin{tabular}{l} 
A R T I C L E I N F O \\
\hline Article history: \\
Received: 20 March, 2019 \\
Accepted: 26 October, 2019 \\
Online: 22 November, 2019
\end{tabular}

Keywords:

Adhesive

Roof tiles

Water hyacinth fiber

Mechanical properties

\begin{abstract}
A B S T R A C T
Problem statement: In general, the water hyacinth is a biennial aquatic plant for many seasons with propagated quickly to become serious weeds in general water sources. The water hyacinth is caused carbon dioxide in the atmosphere as a greenhouse effect, which leads to climate change, the environmental concerns of the world today. The agricultural residue materials are the most used manufactured material in the world through a lot of water hyacinth plant but a little is used efficiently. One approach to reduce agricultural waste and add value to them is to produce a fiber composite like roof tiles. Roof tiles are a product developed to replace natural fiber by mixing agricultural residues materials containing fiber such as rice straw, kenaf, corn cob, rice husk and palm fruit bunch. with adhesives, waterproof adhesives or other materials. Approach: This work is also aimed to investigate the influence of adhesive on roof tiles product from water hyacinth fiber. The urea-formaldehyde adhesive was added into the water hyacinth roof tile in $10 \%, 12 \%$, and $14 \%$ weight ratios. It is then hot pressed and tested to determine physical, mechanical and thermal properties according to the industrial standard. Other factors are considered: temperature compression, the shape of roof tiles and distribution of moisture to roof tiles, heat transfer between sheets during compression, compression time, suitable compression and hardening before or after glueing of the adhesives. Results: The experimental observation revealed that the proportion obtained of $12 \%$ of the Ureaformaldehyde adhesive from the weight of the water hyacinth roof tile mixture, will absorb the adhesive better. Conclusion: With knowledge and technology, the roof tiles manufactured from water hyacinth can raise the quality of life as an innovative product for commercial utilization.
\end{abstract}

\section{Introduction}

The water hyacinth is a biennial aquatic plant for many seasons with propagated quickly to become serious weeds in general water sources, especially in Thailand and Southeast Asia. The weeding of water hyacinth plant residues causes carbon dioxide in the atmosphere as a greenhouse effect, which leads to climate change, the environmental concerns of the world today. The agricultural residue materials are the most used manufactured material in the world through a lot of water hyacinth plant but a little is used efficiently. One approach to reduce agricultural waste and add value to them is to produce a fiber composite like roof tiles.

Although water hyacinth is seen in many countries as a weed and is responsible for many of the problems outlined earlier in this fact sheet, many individuals, groups and institutions have been able to turn the problem around and find useful applications for plant.

The agricultural fiber residue materials are the most used manufactured material in the world through a lot of water hyacinth plant but a little is used efficiently. One approach to reduce

\footnotetext{
*Arkom Pasilo, +668 3464 7155, arkom_pasilo@yahoo.com
}

agricultural waste and add value to them is to produce a fiber composite like roof tiles. Roof tiles are a product developed to replace natural fiber by mixing agricultural residues materials containing fiber such as rice straw, kenaf, corn cob, rice husk and palm fruit bunch. With adhesives, waterproof adhesives or other materials.

The water hyacinth plant and adhesive are also contributed to higher heating bills. The increased density of the roof tiles will result in parts that are mixed with adhesive. If the roof tiles has low density, it will cause more rooms and make low thermal conductivity. On the other hand, if the extrusion roof tiles has higher density, it will get high thermal conductivity, while the heat resistance is low. However, the thermal conductivity of each materials also depends on the structure of the materials, in particular, crystalline shape and the temperature during the extrusion. As a result, the thermal conductivity differs from one material to others. [1]. The surface of building materials which expose directly to the outside air temperature and the sun light will absorb heat radiation. It makes this area get higher temperature than other surface areas. As a result, it causes the temperature differences between the outside air and the exposed surface of the exterior building materials. Thermal energy from 
this area is also transferred to some surface adjacent to a lower temperature by the amount of heat transferred in each direction based on the thermal resistance and the mass of the building. Agricultural fiber residues used as raw materials in the roof tiles product are rice straw, corn cobs, bagasse, pulp, kenaf, palm fruit bunch, and oil plam fiber [2-3].

This work is also aimed to investigate the influence of adhesive on roof tiles product from water hyacinth fiber. The roof tile containing different percentages $10 \%, 12 \%$, and $14 \%$ of Ureaformaldehyde adhesive from the weight of the mixture as shown in Table 1. It is then hot pressed and tested to determine physical, mechanical and thermal properties according to the industrial standard. Other factors are considered: temperature compression, the shape of roof tiles and distribution of moisture to roof tiles, heat transfer between sheets during compression, compression time, suitable compression and hardening before or after glueing of the adhesives.

Table 1 : The specimens sample in this study

\begin{tabular}{|c|l|c|}
\hline \multirow{2}{*}{ Specimens name } & \multicolumn{1}{|c|}{ Adhesive : Fiber } & Content (\%) \\
\hline \multirow{2}{*}{ A-1 } & Urea-formaldehyde & 10 \\
\cline { 2 - 3 } & Water hyacinth & 90 \\
\hline \multirow{2}{*}{ A-2 } & Urea-formaldehyde & 12 \\
\cline { 2 - 3 } & Water hyacinth & 88 \\
\hline \multirow{2}{*}{ A-3 } & Urea-formaldehyde & 14 \\
\cline { 2 - 3 } & Water hyacinth & 86 \\
\hline
\end{tabular}

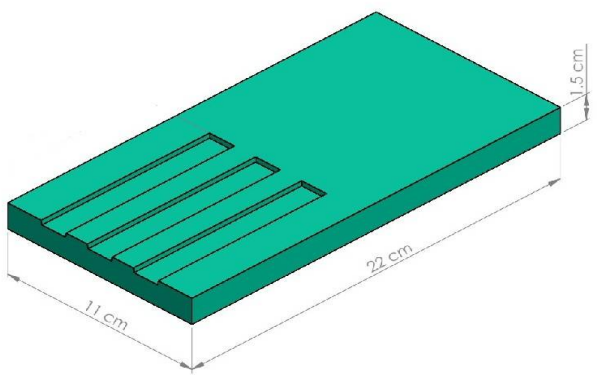

Figure 1. Illustrate the specimen size of roof tiles

\section{Material and Methods}

\subsection{Materials}

The water hyacinth fiber that using in this study

The illustrate of specimen size using of roof tiles in this study is $11 \times 22 \times 1.5 \mathrm{~cm}^{3}$. as shown in Figure 1.

The experiment was performed using the $100 \mathrm{TON}$ universal testing machine as shown in Figure 2. The factors are considered:

- Water hyacinth fiber were cut into small size and moisture content of $2-5 \%$ after adhesive additions.

- $10 \%, 12 \%$ and $14 \%$ of Urea-formaldehyde adhesive content with $1 \%$ emulsion wax and $2 \%$ hardener chloride were thoroughly combined and sprayed onto the water hyacinth fiber mixture (Specimens name: A-1,A-2 and A3 ). The adhesive coated water hyacinth fibers was spread evenly in the mold.

- The temperature compression at $150{ }^{\circ} \mathrm{C}$, heat transfer between sheets during compression. The hot-pressed process under pressure of $180 \mathrm{~kg} / \mathrm{m}^{2}$. (12.41 bar), for 15 minutes.
- The shape of roof tiles, The weight of 533.7 grams and density of $600 \mathrm{~kg} / \mathrm{m}^{3}$ were produced.

- The extrusion method is useful for the modelling and analysis of the problems which a response of interest is influenced by several variables and the objective is the optimization of yield. Which process of extrusion method follows in Figure 3.

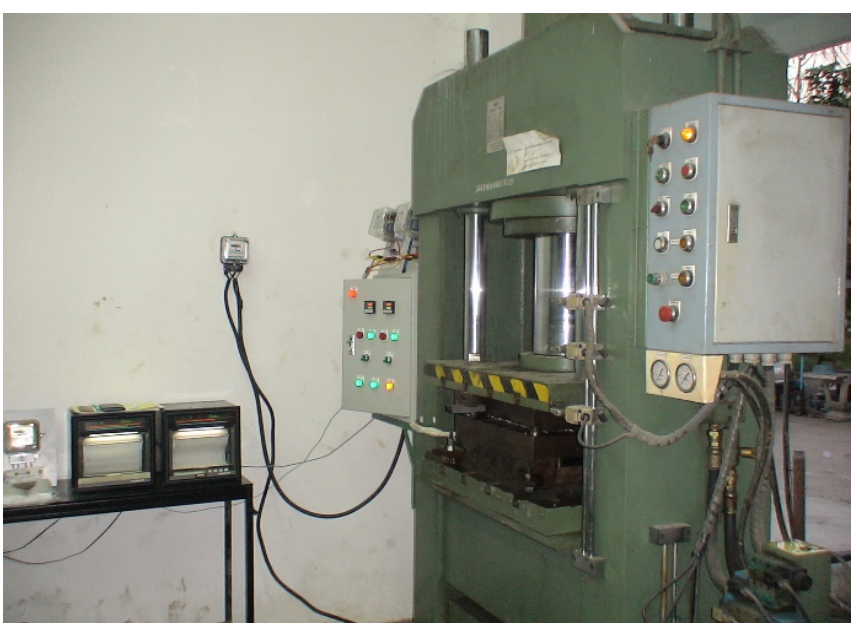

Figure 2. The 100 TON universal testing machine

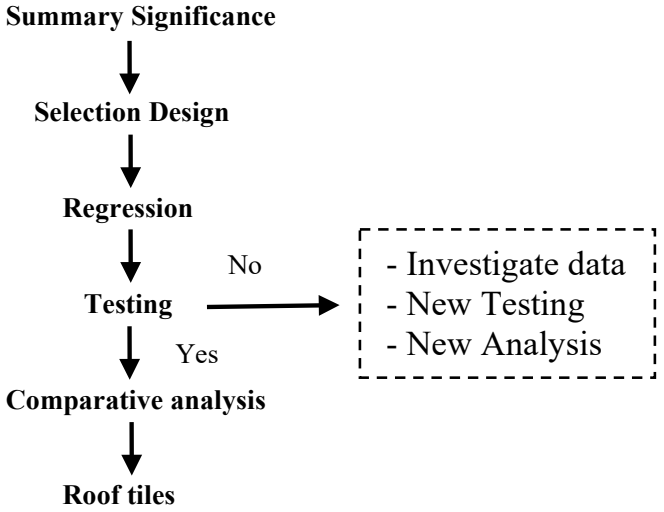

Figure 3. Process of extrusion method

\subsection{Experimental procedure}

The physical, mechanical and thermal properties were tested as follows. [4-5].

Physical properties testing: Density (D) was tested according to TIS 876-2547.

Mechanical properties testing: Modulus of Rupture (MOR) and Modulus of Elasticity (MOE) of roof tiles were according to TIS 535-2540.

Thermal properties testing: Thermal conductivity $(\mathrm{K})$ was tested according to ASTM C 117- 2010.

And all the test was repeated on 3 specimens.

\section{Results and Discussion}

The presented laboratory results, the extrusion of roof tiles is according to the factors defined in all respects. Figure 3 shows the water hyacinth fiber residues deformation of roof tiles. 


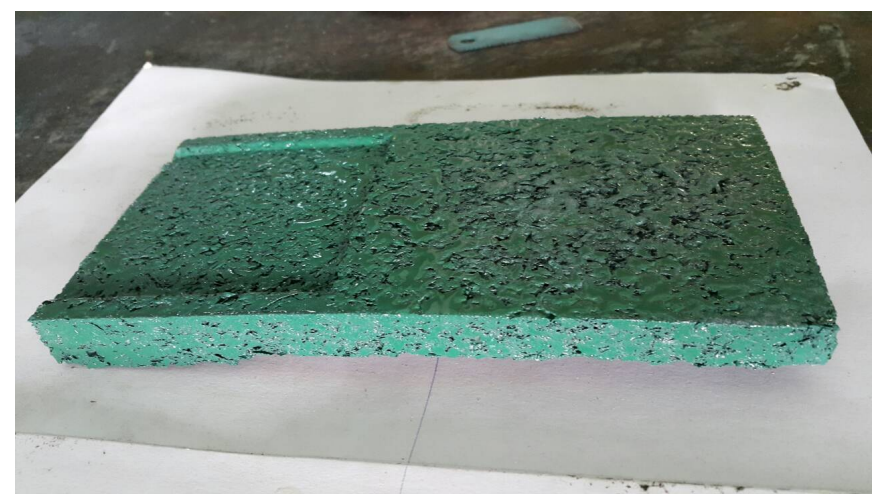

Figure 4. The deformation water hyacinth fiber of roof tiles

Table 2: The summarizes of the roof tile containing the adhesive

\begin{tabular}{|c|c|c|c|c|c|}
\hline Fiber & $\begin{array}{c}\text { Adhesive } \\
\text { Content } \\
\mathbf{( \% )}\end{array}$ & $\begin{array}{c}\text { D } \\
\left(\mathbf{k g} / \mathbf{m}^{\mathbf{3}}\right)\end{array}$ & $\begin{array}{c}\text { MOR } \\
\mathbf{( M P a )}\end{array}$ & $\begin{array}{c}\text { MOE } \\
\mathbf{( M P a )}\end{array}$ & $\begin{array}{c}\mathbf{K} \\
\mathbf{( W / m . K )}\end{array}$ \\
\hline \multirow{2}{*}{$\begin{array}{l}\text { Water } \\
\text { hyacinth }\end{array}$} & 10 & 112.19 & 1.01 & 130 & 0.024 \\
\cline { 2 - 6 } & 12 & 581.31 & 225.75 & $44,500.10$ & 0.098 \\
\cline { 2 - 6 } & 14 & 822.09 & 389.43 & 70,000 & 0.039 \\
\hline
\end{tabular}

Table 2 summarizes the roof tile containing of $12 \%$ of Ureaformaldehyde adhesive from the weight of the mixture is best extrusion of roof tiles molded, with $10 \%$ being unable to be molded and $14 \%$ having too much density and strength. Due to the proportion obtained of $12 \%$ of the Urea-formaldehyde adhesive from the weight of the water hyacinth roof tile mixture, will absorb the adhesive better.

The results suggested that the roof tile containing different percentages $12 \%$ of Urea-formaldehyde adhesive is suitable ratio. This may be because the adhesive can hold with the water hyacinth fiber better than $14 \%$ and $10 \%$ respectively. In addition the roof tiles properties are suitable for the requirements such as density, strength and thermal conductivity. It is also found that the properties of the roof tiles according to the testing standards specification.

Table 3: The results of roof tiles properties

\begin{tabular}{|l|c|c|}
\hline \multicolumn{1}{|c|}{ Properties } & $\begin{array}{c}\text { Water hyacinth } \\
\text { roof tiles (A-2) }\end{array}$ & Standard test \\
\hline Density (D), kg/m ${ }^{3}$ & 581.31 & 800 \\
\hline Modulus of Rupture (MOR), MPa & 225.75 & 270 \\
\hline Modulus of Elasticity (MOE),MPa & $44,500.10$ & 68,000 \\
\hline Thermal conductivity (K), W/m.K & 0.098 & 0.013 \\
\hline
\end{tabular}

The results of properties were shown in Table 3. The physical, mechanical and thermal conductivity with water hyacinth fiber were investigated. It showed that the roof tiles of density do'nt pass the roof tiles specification. For the Modulus of Rupture (MOR) and Modulus of Elasticity (MOE) meet the requirements. However, Thermal conductivity (K) pass the standard. Anyhow, the roof tilles with increasing amount of water hyacinth fiber and adhesive have an issue of dissolving.

\section{Conclusion}

- The results are summarized as follows:

- The proportion obtained of $12 \%$ of the Urea-formaldehyde adhesive from the weight of the water hyacinth roof tile mixture, will absorb the adhesive better.
- Knowledge and technology, the roof tiles manufactured from water hyacinth fiber residues can raise the quality of life as an innovative product for commercial utilization.

- The potential further studies from the findings of this paper include the possibilities of using the roof tiles produced within the climatic characteristics and sustainability of the roof tiles produced [6].

- In the future, this is a roof tiles product to be benchmarked with industrial production process [7]. They are the economic analysis and the durability in exposing to sun light.

\section{Acknowledgment}

The authors would like to express their sincere thanks to Faculty of Engineering, Ubon Ratchathani University for financial support.

\section{References}

[1] R.H. Myers and D.C. Montgomery, Response Surface Methodology : Process and product optimization using designed experiments, Forth ed, John Wiley \& Sons Press, 2016.

[2] Yan Li, Yiu-Wing Mai and Lin Ye, "Sisal Fibre and its composites: a review of recent developments" Composites Science and Technology. 60, (2037-2055), 2000. https://doi.org/10.1016/S0266-3538(00)00101-9

[3] Standard Test Method for Steady-State Heat Flux Measurements and Thermal Transmission Properties by Means of the Quarded-Host-Plate Apparatus ASTM C177-10, Annual Book of ASTM Standards, 2010.

[4] A. Pasilo, U. Teeboonma, "Development of roofing tiles manufactured from agricultural residues", $11^{\text {st }}$ Conference on Energy Networkof Thailand (E-NETT): 1142-1148, Chonburi, Thailand, 2015.

[5] A. Pasilo, U. Teeboonma, "Investigation of the properties of roofing tiles manufactured from agricultural residues" in 2016, International Conference on Advanced Material Science and Mechanical Engineering, (AMSME -E140): Central Station Hotel, Bangkok, Thailand, 2016.

[6] Ahmad Al Yacouby, Mohd Faris Khamidi, Muhd Fadhil Nuruddin. and Syed Ahmad Farhan. "Study on roof tile's colors in Malaysia for development of new anti-warming roof tiles with higher Solar Reflectance Index (SRI)", Progress in ResearchGate, September, 2011. https://doi: 10.1109/NatPC.2011.6136358

[7] Peter O. Akadiri, Ezekiel A. Chinyio and Paul O. Olomolaiye. "Design of A Sustainable Building: A Conceptual Framework for Implementing Sustainability in the Building Sector", Buildings, ISSN 2075-5309, 2, (126152), 2012. https://doi:10.3390/buildings2020126 